\title{
REALITIES, SURREALITIES AND THE MEMBRANE OF INNOCENCE
}

\author{
Tony Barta
}

A funny thing happened to me on the way to Genocide Studies: I was called a surrealist. I was not so sure it was a compliment when I first heard it 30 years ago. And I only heard it through Colin Tatz, who then told the world about it. I had delivered my very first paper on genocide, at a conference called "On Being a German- Jewish Refugee in Australia.” The problem was that I wanted to discuss how the genocide in everyone's minds, the Holocaust, inhibited consciousness of the violent past that had enabled us to meet on ground named after the colonial secretary, Lord Sydney. The question was equally suppressed where I had settled with my family, the city named after Lord Melbourne.

The conference went well. The trouble came when I attempted to explain to a Jewish audience at the Hakoah Club that these cities might be named after civilised gentlemen, but they were founded on genocide. That did not fit with the consciousness of many in the audience. I caused unease, then outrage. Konrad Kwiet, behind me, urged, "Mention your mother, mention your mother." She was sitting in the front row. It did not come to that. I was thrown from the platform by a young Zionist who went on to become an important lawyer. When it came to publishing the papers, the editors, John Moses and Kwiet, decided to include mine, though according to Tatz, they asked him whether my "surrealistic" vision belonged there. ${ }^{1}$

Generally, when we talk about the surreal we mean something strange, outside everyday reality, disconcerting. For me, the word had a quite different resonance. I recalled a debate in the seventies about how knowledge is socially constructed and made culturally meaningful. Objective historical knowledge in the present is only achieved with a sense of how subjectivity constructs the past. Philosopher Robert Solomon's book The Passions argued for a more extensive and intensive embrace of subjectivity. His chapter devoted to the individual nature of all perspectives was titled "Surrealism."2

1 Tony Barta, “After the Holocaust: Consciousness of Genocide in Australia," Australian Journal of Politics and History 31, no. 1 (1985), 154-61; Colin Tatz, "Confronting Australian Genocide,” Aboriginal History 25 (2001), 16-36; the recollection is reprinted in Colin Tatz, With Intent to Destroy: Reflecting on Genocide (London: Verso, 2003), 102-03.

2 Robert C. Solomon, The Passions (New York: Anchor Doubleday, 1976), chap. 3; see also, Clifford Geertz, 
Solomon wished to distinguish his position from one that says individual perspectives create reality. He believed, as do I, that in a comprehensive sense, there is only one reality but any person can only comprehend that reality in part, and from an individual perspective:

Surreality is Reality from a point of view, limited by our personal experience and edited for brevity and manageability as well as for dramatic considerations. Objective reality is all here now, all at once. Subjective surreality, on the other hand, can handle only a small piece of Reality at any one time.

That definition takes us straight to the problem I encountered at the Hakoah Club. Anyone interested in the multiplicity of perspectives, paradigms and interpretations that jostle within genocide studies, needs to ponder surreality. My own perspective on genocide, and genocide studies, would be to highlight this interplay between historically constructed expectations, blind spots, prejudices and decisions, the context that produced them-and subsequent outcomes. Solomon gives a special place to "values"; the source of values, he says, is the passions. I would never exclude emotion or indeed physiological drives and pathologies. Yet, because I am especially interested in intentions, interests and unintended consequences, I look to the limitations of knowledge or feeling in a potentially disastrous situation. In Solomon's example:

The psychologist Kurt Lewin compares the "lifeworlds" of two men crossing dangerously thin ice in a carriage; one knows the danger, the other does not. The "facts" (the Reality) are the same for both of them; their surrealities could not be more different.

The thin ice in genocide studies is a complex of historical realities very few actors are likely to know. Many of us assume people in Nazi Germany knew where things were headed. Mostly they did not. Such psychological realism is crucial in the key question of intent. Intent looks readily demonstrable if searching the documents yields a smoking gun. But reading documents often means reading actions. By their actions we must know them.

My argument has always been that the intentions of a settler "taking up" land outside Melbourne can seem to him (and to us) genuinely innocent of 
genocidal intent. A genocidal outcome nevertheless results. Only by construing the actions within a broader complex of culture and societal and individual interests, can we begin to understand the larger factors in play. Some reasons will have been personal (to impress a parent or a fiancée), some as impersonal as a worldwide colonial project. It seems obvious that a history will benefit more from a sense of different surrealities when it has information specific to an individual. Culture and interests are not, however, only personal, any more than a consciousness of history is. The ways these matters are construed, at the time and later, depends on our conceptual framework, most importantly on the way we conceive of relations. How are the thoughts and actions of an individual to be understood in relation to the larger contexts of economy, coercive power, society, culture, ideology?

\section{Layers of surreality}

It does not take much theorising to agree that people acting in the past (that is, their present) acted within a history we are now able to conceptualise into different factors and contexts. The question is how to represent their realities and surrealities to enhance our understanding. Too often we simply resort to our old friend "common sense." This is both vital and hazardous in genocide studies. Vital because it reminds us to check our reference base, and hazardous because it leads to false assumptions about empathy and equivalence.

Our common sense assumption is that the most direct access to a surreality in the past is through the memory of a person who experienced the situation. Common sense also tells us there are complications in the ways people remember and represent their own experience. Remembering Genocide, edited by Nigel Eltringham and Pam Maclean, reminds us that memory is not a passive storage system, not an image bank of the past, but an active, dynamic, shaping force. The editors quote Raphael Samuel's warning that it is "historically conditioned to the emergencies of the moment. ... Like history, memory is inherently revisionist and never more chameleon when it appears to remain the same." ${ }^{3}$ That said, memory is unparalleled and indispensable in the access it gives us to the past.

Each of us can think of memorable instances even as we remember the caveats about memory and retelling. Often we listen with a special consideration of a general kind, assuming a further surreality of trauma, which involves

3 Pam Maclean, "To be Hunted like Animals: Samuel and Joseph Chanesman Remember Their Survival in the Polish Countryside during the Holocaust” in Remembering Genocide, eds. Nigel Eltringham and Pam Maclean (New York: Routledge, 2014). The quote from Raphael Samuel is from Theatres of Memory (London and New York: Verso, 1994), 1.x. See also works by Zoe Waxman and Pascale Bos on gender and memory. 
the protection of self and others, the effects of repeated recounting, and confidence or doubt about creating conviction in the listener. Nevertheless, the stories told do carry weight. This is especially so in the case of the Holocaust where we rely on the accounts of survivors - and a small number who did not survive- to convey the surreality of victimisation. Because the imagery of the slaughter is so hellish, with its herding, gassing and burning of bodies, it is also the most surreal in a more conventional sense, but that is not what I mean here. What I am trying to chase down is our access to the experience and the larger realities recognised or unrecognised in that particular experience.

Our sense of victim experience is by far the most powerful and pervading due to the extensive testimonies of survivors. Testimony and memoir are also by far the most common source for reconstructing the surreality of perpetrators. We have the accounts of Franz Stangl, Rudolf Höss and a few other officers, and we have the trial records. If the most damning testimony in trials was that of victims it was because the self-exculpating testimony of the accused was not considered to give the court access to the all-important mens rea, the incriminating state of mind at the time of the offence. No amount of badgering could elicit from Adolf Eichmann a confession of murderous intent. It had to be proven by inferences from deliberately euphemistic documents, the testimony of his victims-and from his actions. ${ }^{4}$

Because action (or inaction) is so challenging to construe, "bystanders" are always problematical in their links to a genocide. Sometimes they are literally bystanders at an episode of discrimination or violence, yet more often they are far from the scene and very often genuinely innocent-in which case, they may be better described in Tatz's conceptualisation, as "beneficiaries." In the case of the Nazi genocide of Europe's Jews, we have been almost as much fascinated by the surrealities of "ordinary Germans" as we are with the "ordinary men" who became killers. Those far from the scene aroused more interest in earlier decades, when collective guilt became a legacy of post-war preoccupations. Books like Milton Mayer's They Thought They Were Free and William Sheridan Allen's The Nazi Seizure of Power were staples of teaching in the 1970s. In biographies of ordinary Nazis or "The Experience of a Single German Town," we found access to the lives of Germans before the worst atrocities were perpetrated.

4 Essential documents remain in several versions including Heinrich Himmler's speeches to his officers, especially the address at Poznan: http://www.nizkor.org/hweb/people/h/himmler-heinrich/posen/oct-04-43/ ausrottung-transl-nizkor.html. See also Rudolf Höss, Death Dealer: The Memoirs of the SS Kommandant at Auschwitz, ed. Steven Paskuly, trans. Andrew Pollinger (Boston: Da Capo Press, 1996); Gitta Sereny, Into That Darkness: An Examination of Conscience (New York: Vintage, 1974); Gitta Sereny, Albert Speer: His Battle with Truth (New York: Vintage, 1996); Bettina Stangneth, Eichmann Before Jerusalem: The Unexamined Life of a Mass Murderer (New York: Knopf, 2014). 
Such access has been one basic ambition of modern history over the past two centuries. Where traditional accounts were more concerned with making a meaningful narrative, we have more recently wanted to know "how it actually was." For some historians that still means the formation of policy, for others an account of large events that swept up individuals. The experiences of individuals have now achieved a dominating popularity, with biography a staple of historical bestsellers. What is known as "ethnographic history" attempts to read the actualities of individual perspectives - surrealities - by interpreting historical episodes within an understanding of cultures. History must situate both culture and individual experience within economic, societal and political contexts, and these contexts are also needed to understand any episode of genocide.

Genocide Studies in the academy are scarcely 30 years old; ethnographic history is about a decade older. How many genuinely ethnographic accounts of genocide have we produced in that time? The studies of specific Nazi atrocities by Christopher Browning, Jan Gross and Claude Lanzmann take us very close to the action — of ordinary men committing massacres or filling a lorry with Jews for gassing. Gross follows neighbours in a Polish village doing their part. Konrad Kwiet's "From the Diary of a Killing Unit” shows how the mentality of bicycle policemen transforms once they are far from the familiar streets of Vienna. ${ }^{5}$

The notion that individual actions need to be read very carefully, alongside maximum historical information and theoretical assistance, has become standard in ethnography. Here, as Inga Clendinnen reminds us, neither common sense nor its bedfellow, intuition, are much help. Engaging in open discussion of interpretive options "reduces the role of untestable 'intuition' by making the business of interpreting actions a public affair: it inhibits the casual offloading of our own expectations onto unlike others." ${ }^{6}$ The interpretation of cultures, as Clifford Geertz argued, can only proceed by a hermeneutic process that goes beyond attentive observation. Understanding and creating understanding is something elaborate, educated and subtle. To illuminate an action, we need to consider what will be most effective from the plethora of theories and methods our libraries hold.

In studies of Australian genocide, the groundwork of ethnographic history

5 Konrad Kwiet, "From the Diary of a Killing Unit” in Why Germany?: National Socialist Anti-Semitism and the European Context, ed. John Milfull (Oxford: Berg, 1993), 75-90; Christopher Browning, Ordinary Men: Reserve Police Battalion 101 and the Final Solution in Poland (New York: HarperCollins, 1993); Jan T. Gross Neighbors: The Destruction of the Jewish Community in Jedwabne, Poland (Princeton: Princeton University Press, 2001).

6 Inga Clendinnen, Reading the Holocaust (Melbourne: Text, 1998), 138. 
began quite early, before the term was invented. More recently, records, memories and local studies have not produced many analyses in terms of colonial settler culture. ${ }^{7}$ Explicating genocidal realities in the USA has been similarly fitful. ${ }^{8}$ Perhaps because we have a stronger ethnographic tradition in studying peoples further from home, the accounts of genocide in Cambodia, Rwanda and Central America are more culturally engaged. They have given us some of the best examples of where an anthropologically curious and ethnographically persistent kind of genocide study can take us.

Alexander Hinton has reflected on some of the challenges. He has spoken of his early interest in Buddhism, in folk psychology, emotion, stories. How could Cambodians do this? The cover of his book Why Did They Kill? has an apt summary: "Hinton considers this violence in light of a number of dynamics, including the ways in which difference is manufactured, how identity and meaning are constructed, and how emotionally resonant forms of cultural knowledge are incorporated into genocidal ideologies.” The foreword to another of his books, Annihilating Difference, asks:

What combination of hatred and fear leads people to see their neighbours not as fellow human beings entitled to lead their own lives but as an intolerable presence that must be isolated and eliminated? Human rights activists seek to monitor, curb, and punish such atrocities. They identify proximate causes or individuals who bear special responsibility. But in a fundamental sense they do not really explain these abuses. For a deeper explanation, they must turn to other disciplines. In this quest, anthropology has much to offer. ${ }^{9}$

7 Some sources are indicated in Tony Barta, “ 'They appear actually to vanish from the face of the earth.' Aborigines and the European Project in Australia Felix,” Journal of Genocide Research 10, no. 4 (2008), 519-39. Judith Wright, The Cry for the Dead (Melbourne: Oxford University Press, 1981) stands out among memoirs that also try to indicate the genocidal realties and surrealities of settler culture. On Wright, and Clendinnen, see Tom Griffiths, The Art of Time Travel: Historians and Their Craft (Melbourne: Text, 2016).

8 Some of the most illuminating histories do not have genocide in their vocabulary. Ned Blackhawk, Violence over the Land: Indians and Empires in the Early American West (Cambridge, Mass: Harvard University Press, 2006) refers to "genocidal" events, also plainly addressed in Jeffrey Ostler, The Plains Sioux and U.S. Colonialism from Lewis and Clark to Wounded Knee (New York: Cambridge University Press, 2004); Stephen Howe, "Native America and the Study of Colonialism, Part 1: Contested Histories," Settler Colonial Studies 3, no. 1 (2013), 102-26, and "Native America and the Study of Colonialism, Part 2: Colonial Presents," Settler Colonial Studies 4, no. 1 (2014), 105-19. Not to be missed: Ken Burns and Stephen Ives, The West (New York: Insignia Films, 1996), DVD.

9 Alexander Laban Hinton, ed., Annihilating Difference: The Anthropology of Genocide (Berkeley: University of California Press, 2002), 1-6. Nancy Scheper-Hughes adds, "Public anthropology [is about] making things public that are private. Making invisible things into public issues, making visible secrets that empower some and disempower others who are not privy to the information.” Located in Aleksandra Bartoszko, "Being Radical without Being a Leftist: Interview with Nancy Scheper-Hughes,” antropologi.info (blog), http://www.antropologi.info/blog/anthropology/2011/nancy-scheper-hughes. 
Not all historians value the help of other disciplines, and we certainly do not want to erase the differences. Individual proclivities—and surrealities-will shape the ways we seek to create understanding.

\section{Surrealities of writers and readers}

Writing history is not easier than other forms of writing. Our own personal dispositions are crucial to the perspectives we adopt. We will all conventionally acknowledge a rather formulaic subjectivity, derived from our own historical context and life experience. We are inclined to be reticent, perhaps mercifully, about our own surrealities, the interplay of intimate, emotional and societal factors that are probably crucial to the kind of history we write and read. Even such an obvious personal constriction as the languages we know and do not know, something that is just as obviously linked to the largest dynamics of world history, rarely rates a mention. In Australian history our language limitations are manifest — and almost always passed over in silence. To recognise how many hundreds of languages have disappeared would be to implicate our everyday selves in genocide. The Great Australian Silence was upheld by the writers and the readers of the history they complacently shared.

If every historian writes from a unique personal experience and a shared historical encounter, there is also a more institutional factor in the shaping of historical consciousness. Greg Dening once memorably compared the mindsets of academic disciplines to an old horse ploughing its furrow and we all know examples (ourselves included) that fit. The strictness of our blinkers, the matters we choose for attention, the assumptions we bring to the interpretive venture, the paradigms we apply-all these are brewed in the surreality we inhabit. To the extent the surreality inhabits us, it commands our focus and our scope. How much is nature and how much nurture is interesting to pursue; all of us have our own mix. ${ }^{10}$

Where does this matter in genocide studies? Almost everywhere. What we give attention to, when and how persistently we examine a question of genocide, indeed whether we even see a question of genocide: every impulse of our enquiry is provoked, vetted, or encouraged by our individual surreality. As we shall see again, when we turn to our audience, each surreality is of course a construct of history, society, culture and ideology. These are the very large contexts that control something as fundamental as the definition of genocide we adhere to, or which elements of the standard definitions (Lemkin's

10 The draught horse Eustace makes a repeat appearance in Greg Dening, Performances (Melbourne: Melbourne University Publishing, 1996). See also Griffiths, The Art, chap. 6. 
1944 chapter, or the clauses of the UN Convention) we deploy. When we add the more intimate contexts-family, friends, academic environment, those we wish to win approval from-we can see that the whole field of genocide studies is likely to be skewed by dominating, but not usually acknowledged, surrealities.

The influence of such factors is over and above (sur) or underneath (sous) our choice of which reality we focus on and how we go about it. To concentrate on legal questions, as William Schabas does, or on massacres, as Lyndall Ryan and Benjamin Madley do, means breadth and depth in our understanding of genocide. There is no reason to promote one expertise over another. Nor can inclinations towards empirical or theoretical pursuits claim any superiority. I will end up arguing that all treatments of genocide are not created equal because I believe all writers should attend to the surrealities of their subjects and attempt to follow them through to their historical contexts-social, cultural, political, economic. I have an open bias towards intellectual constructs, utilising what Geertz called "made in the academy concepts" to interpret events. But I also have a bias towards less explicit representations, the kind that leaves much implicit, that relies more on artistic flair to give us access to the worlds of others. Writers (and filmmakers) with such talents have usually had them nurtured outside of the academy. We all have examples of true stories or made up ones that have the power to transport us into the experiences of others. Fiction relies on this power but memoirs can have it, too. (I once had the nerve to suggest to Raimond Gaita that he write no more books because he had achieved close to perfection in Romulus, My Father.) If we want the feeling of taking part in an atrocity, or surviving one, we will turn to a writer who knows the art of recreating a surreality.

Imagination is the heart of the matter. Each interpretive enterprise relies on the talent of the writer that will enable the reader to inhabit something of another's reality. Fiction has the most immersive potential and its poetics can sometimes cultivate, rather than smother, our critical faculties. A more prosaic kind of explication might foreground the analytical capacity of writer and reader, but the surrealities in play will only come through if the more imaginative arts allow them to. For access to individual cases we still rely mainly on memoir, fiction and encounters through film. The art of novelists (Lion Feuchtwanger to Jonathan Franzen) and filmmakers (Leni Riefenstahl to Edgar Reitz) have given us more insight into Nazi allegiance on the one hand and the ideology of innocence on the other. The closer we get to the realities of Nazi Germany, and the surrealities of German people, the less we will see these characterisations as alternatives. ${ }^{11}$

Strategies of meaning-creation implicitly have a target audience. For acad- 
emic work it is other academics. Within that audience we will have in mind a more circumscribed set we may or may not be part of, and certain individuals whose opinion we value. We may hope to strengthen ties within professional networks or at least not alienate colleagues. For whom, with what intellectual interests and prejudices, am I writing? What qualities am I searching for in a wider circle of possible readers? With which elements of their surrealities am I seeking to make a connection?

The perspectives of our audience are not really the end-point of our work. They are the primary ones. Their surrealities govern the reception of the accounts we give. I learned about their power the hard way in that first encounter at the conference in Sydney. Recently, at the other end of my career, I stopped to check with a large lecture hall that my reference to Clifford Geertz had some resonance. It did not. The great ethnographer had not been dead 10 years and for this audience of genocide scholars he was scarcely a whisper. We can assume very little, even in a specialist audience, about a shared set of references, understandings, responses. As with all representations-visual, written, musical-we cannot assume that our surreality evokes a similar reverberation in someone else's.

All historians strive to make past understandings real to their readers. Where we rely on translation, as in so much writing on the Holocaust, we need to be aware that almost any word or set of words can skew the meaning of the original. We can build up crippling scruples about tone and nuance. Beyond the hideous distortions in the language of the Nazis (memorialised by Viktor Klemperer) are the historical, cultural and intimately personal specifics faced by all translators. Anyone bilingual knows the pull of one language or the other for just the right, often untranslatable word. For the difference a word makes in conveying a meaning-and with it a surreality-see the attention J.M. Coetzee pays to Franz Kafka and his translators. He needs a page to show how one sentence of interior experience can be wrong, word after word. ${ }^{12}$ The experience examined is making love. Should we have less care with the experience of separating children from mothers for killing?

Film has a special place in the representation of surrealities because it deploys, and employs, powers that are the most deeply learned and practised in human communication. To read the face and voice and demeanour of another,

11 Tony Barta, "Recognizing the Third Reich: Heimat and the Ideology of Innocence," in History on/and/ in Film, eds. Tom O’Regan and Brian Shoesmith (Perth, 1985), 131-39. For earlier examples, see Tony Barta, Screening the Past: Film and the Representation of History (Westport: Praeger, 1998), chap. 8, and chap. 9, a discussion of television and history with Pierre Sorlin. Also Tony Barta, "Consuming the Holocaust: Memory Production and Popular Film,” Contention 5, no. 2 (1996), 161-75, and the 2014 film Labyrinth of Lies.

12 J.M. Coetzee, “Translating Kafka,” Stranger Shores, Essays 1986-1999 (London: Vintage, 2002), 88-103. 
a skill that predates literacy by millennia, is acquired in the first months of life. Even as we watch for signs of deception we build our confidence in our ability to access another's experience by watching and listening. This encounter is the basis of "documentary" interviews with survivors, and sometimes perpetrators, of genocide. There is almost always a degree of acting in such accounts and the acting in fictional films also depends on our suspension of disbelief. Once we become critically aware of how film manipulates our senses to supposedly give access to the inner reality of another person, suspicions can multiply. Some of the most successful art makes us aware of artifice even as it inducts us into an extreme rendering of a past horror. Think of Lanzmann's stolid persistence in Shoah, the little girl with the red coat in Steven Spielberg's monochrome Schindler's List, and the old-format framing throughout Son of Saul. All attempt to heighten the simultaneous awareness of surrealities as historical reality.

\section{Surreality as reality: interests and ideology, intent and innocence}

We have thousands of attempts to link the prejudices and political choices of Germans to the Holocaust. In Germany, the question resides less in media representations than in quite personal connections to the broad-brush verdicts of collective guilt (you must have known) or collective innocence-how could we have known? Historical judgement between these opposed surrealities has tended to come to questions of historically formed culture and ideology. Unsurprisingly, most Germans have responded negatively to accusations and analyses they see as lacking realism and subtlety. ${ }^{13}$

Raphael Lemkin opened himself to this criticism even as he brought an important aspect of collective responsibility to light. He was a lawyer before he was an historian and his interest in subjectivity did not, so I thought, go much beyond the crucial mens rea. But there turns out to be another Latin tag on which he also placed weight in his judgement of intent. In the preface to Axis Rule he quotes three words followed by a translation: facit cui prodest-he in whose interest it was, did it. ${ }^{14}$ Lemkin insisted that the crimes carried out

13 Dirk Moses has made many contributions to the understanding of post-war surrealities in Germany. Of special relevance here is his discussion of Jürgen Habermas and Martin Walser in "The Non-German German and the German German: Dilemmas of Identity after the Holocaust," New German Critique 101 (2007), 45-49.

14 Raphael Lemkin, Axis Rule in Occupied Europe: Laws of Occupation, Analysis of Government, Proposals for Redress (Washington: Carnegie Endowment for International Peace, 1944), xiv. Subsequent quotations are also from the Preface; Tony Barta, “'He in Whose Interest It Was, Did It': Lemkin's Lost Law of Genocide,” Global Dialogue 15, no. 1 (2013), 12-23 . 
far from hearth and home could not be separated from "important political and moral considerations based upon the responsibility of the German people treated as an entirety":

All important classes and groups of the population have voluntarily assisted Hitler in the scheme of world domination: the military, by training the reserves and working out plans for conquest; the businessmen, by penetrating and disrupting foreign economies through cartels, patent devices, and clearing agreements; the propagandists, by organizing Germans abroad and preparing fifth columns in countries to be occupied; the scientists, by elaborating doctrines for German hegemony; the educators, by arming spiritually the German youth.

Germany's Nazi elite was crammed into the dock but in his "Proposals for Redress" he makes plain that the larger societal involvement implies something very close to collective guilt regardless of the subjective sense of individuals. The surrealities massaged by ideology are trumped by the objective realities of interest:

Indeed, all groups of the German nation had their share in the spoils of occupied Europe. The German Hausfrau used for her family the food of all occupied countries, Polish geese, Yugoslav pigs, French wine, Danish butter, Greek olives, Norwegian fish; the German industrialist used French and Polish coal, Russian lumber; the German employer in agriculture and industry used for his greater profit imported conscript labor; the German business man bought up foreign interests and properties, taking advantage of the debasement of non-German currencies; the importer benefited through low prices and compulsory credits; and by Hitler's decree of July 28, 1942, the access to women in occupied countries was facilitated for German manhood by fiat of law.

In their first essay on genocide, Ann Curthoys and John Docker highlighted the benefits Lemkin listed, and his insistence that all groups who shared the spoils of occupied Europe shared responsibility for the atrocities. Their concern was less Germany than the consciousness of genocide in Australia. ${ }^{15}$ Unlike Lemkin, they were not arguing for guilt, but for a recognition of the suppressed reality of colonisation: genocide.

15 Ann Curthoys and John Docker, “Introduction: Genocide: Definitions, Questions, Settler-colonies,” Aboriginal History 25 (2001), 1-15. 
Robert Manne insisted many years ago that the black armband/white blindfold controversy was not about guilt. It was shame we should feel. ${ }^{16}$ Suppression and repression of the shameful remains the reality/surreality interface in Australian history. There are notable signs of consciousness changing. The weasel word " Reconciliation” is giving way to "Recognition" and "truthtelling." Even "Treaty” has reappeared. "Genocide” is still too confronting for older Australians and is not pushed to the fore by Aboriginal spokespeople. ${ }^{17}$ There are incremental gains to be achieved. There may be generational change under way that may even allow the idea of a treaty onto the agenda. The changes in historical consciousness are due more to Indigenous initiative and public presence than to the labours of historians. Musicians, actors in film and television have made more difference than politicians, with footballers in the front line.

Only a few historians even by the 1990s would attach something as universal as sport and as searingly individual as suicide to a whole history of colonisation. For Colin Tatz, the crisis in Aboriginal communities was not only a matter of alcohol and family violence. "It is a legacy of past violations by a hostile and even genocidal society." Men who did not kill themselves still had a low chance of surviving past 50. Their surreality was closer to football than colonisation but Tatz makes the connection. The Ceduna Rovers won the Far West premiership in South Australia in 1958. "By 1987, less than 30 years later, all but one of the 18 young men were dead."18

Colin Tatz gave his collection of powerful essays a powerful title: With Intent to Destroy. The provenance of the phrase could not be more impressive. Since my first failed attempt to indicate elements of shared responsibility different from explicit genocidal intent, my aim has been to broaden the readings of ultimately genocidal interests and actions. How individual surrealities, focussed on the innocent pursuit of interests, help create a reality in which a genocide is produced, is part of the problem. The other part, determinedly repressing what might surface as intent, is the membrane of innocence.

There was a prologue to my disaster at the Hakoah Club, and an epilogue. In the days before the conference an old friend of my parents asked what had

16 Robert Manne, "Sorry Business: The Road to the Apology,” Monthly, March, 2008, 22-31; Tony Barta, "Sorry, and Not Sorry, in Australia: How the Apology to the Stolen Generations Buried a History of Genocide," Journal of Genocide Research 10, no. 2 (2008), 201-14.

17 Some Indigenous leaders, most eminently Marcia Langton and Noel Pearson, have on occasion used the word genocide, and it has recently been revived in public discourse by Stan Grant, Talking to My Country (Sydney: HarperCollins, 2016).

18 Colin Tatz, Aboriginal Suicide is Different: A Portrait of Life and Self-destruction (Canberra: Aboriginal Studies Press, 2001), 5. On March 31, 2017, ABC news reported that Indigenous youth are 17 times more likely to be in judicial detention. 
brought me to Sydney. Quick as a flash came the perfect response to my mention of Aboriginal genocide. "That wasn't us," he said. "That was the poms.",19

The day after the debacle I returned to the Club to pick up the jumper I had shed before my talk. The woman in the office had not been present but she had heard. It was a pity, she said, that I was not there the previous week. Charlie Perkins had come to address the same audience. He had said how much he could feel their suffering. "You could have heard a pin drop," she said. "He held them in the palm of his hand."

Perkins knew about surrealities. He had lived them and studied them and negotiated them all his life. He knew the strength of the membrane. I came to see he was right. Most Australians still respond to any association with genocide in ways that preclude negotiation. The Perkins' principle is to allow recognition of a reality in the only way possible, within someone's surreality. To recognise that there were many Indigenous peoples and that the many means employed to destroy their unique identities must be classed as genocide may still be a bridge too far. ${ }^{20}$ Yet the 30 years of bridge building must, we hope, make eventual recognition more certain.

Tatz coined a memorable and pertinent phrase when he wrote of breaking through "the membrane that locked or blocked out the unthinkable notion of genocide having occurred in this moral country." It was a membrane of innocence, impervious to a word evoking a distant horror. Tatz lists the many writers who had tried to get Australians to face the facts, some detailing atrocities against Aboriginal peoples, but none connecting massacres and other brutalities of European Australia with the foreign concept, "Genocide”:

No one was reading the Polish international jurist, Raphael Lemkin, who coined the word for the destruction of the genus of a people in 1944. No scholar was looking at the fine print, or at the fact that the United Nations had created an international law which equated physical killing with such acts as imposing birth control measures and forcibly transferring children. We were all steeped in Auschwitz, Treblinka, Sobibor and Belzec, in mon-

19 A British historian has also returned the weight of responsibility to the colonial power. Tom Lawson, The Last Man: A British Genocide in Tasmania (London: I.B. Taurus, 2014). See also John Docker, "A Plethora of Intentions: Genocide, Settler Colonialism and Historical Consciousness in Australia and Britain,” International Journal of Human Rights 19, no. 1 (2015), 74-89. For a contrary view of the effect in historical consciousness, see Rebe Taylor, “Genocide, Extinction and Aboriginal Self-determination in Tasmanian Historiography,” History Compass 11, no. 6 (2013), 405-41.

20 Another Aboriginal language has been buried with Tommy George, the last fluent speaker of Awu Laya on Cape York. He fought a billionaire miner and won but could not save a basic element of his culture. Perhaps because it was a double funeral with his son, there was a report with headline and pictures in the Weekend Australian, August 13-14, 2016. 
strous SS men, in Himmlers, Heydrichs and Hoesses. Who needed to look further than these men and their doings for an understanding of genocide? Who could look any further? ${ }^{21}$

Tatz was one who did look further. His attack on the membrane of ignorance and innocence was sustained and effective. Work on Australian genocide by other scholars combined with Indigenous activism began to bring international attention to bear on our history. I believe the most cited and defining intervention was Tatz's 1999 paper “Genocide in Australia," supported by his path-breaking work on racism. He succeeded in installing genocide studies as an academic discipline with institutional support and founding Genocide Perspectives to stimulate Australian scholarship in an environment of ignorance, ideology and interests resistant to any association with genocide.

Directly confronting the resistance remains something very few Australian historians do. Despite the landmark interventions of two Prime Ministers-Paul Keating's Redfern speech should be the credo taught to every generation of schoolchildren - the key recognition of Australia as a nation founded on genocide scarcely surfaces in our histories. They keep reinforcing the membrane anchored in the ideology of the society at large. But a smaller group of our academic colleagues have recognised something we should be proud of: that genocide, from its invention, is an activist concept as well as a hermeneutic one. Like Raphael Lemkin, we want it to have an effect in changing the world. ${ }^{22}$

21 Tatz, "Confronting Australian Genocide," 18-19.

22 Donna-Lee Frieze, ed. Totally Unofficial: The Autobiography of Raphael Lemkin (New Haven: Yale University Press, 2013); Tony Barta, "Liberating Genocide: An Activist Concept and Historical Understanding," Genocide Studies and Prevention 9, no. 2 (2015), 103-19. 